\title{
空中写真測量による地下すべり面形状解析システム
}

\section{Analytic System for Underground Sliding Geometry of Landslide by Aerial Photogrammetry}

\author{
吉澤孝和*, 酒井輝雄** \\ 宮野尾文夫**, 根 岸 六 郎**, 関 貴 幸*** \\ Norikazu YOSHIZAWA, Teruo SAKAI \\ Fumio MIYANOWO, Rokurou NEGISHI, Takayuki SEKI
}

\begin{abstract}
Aerial photogrammetry is powerful technique to monitor landslide behavior effectively and safely. Using three dimensional displacement (3DD) vectors of ground points, which are detected by photographs taken at different time flights on a landsliding area, velocity and direction of ground movement can be visualized on a map or projection plane. Moreover, we can presume geometry of underground slide surface by analysis of the 3DD vectors. This paper treats a landslide that had abruptly occurred at Hirose in Nagano city. Its characteristic was small-area, rapid-growing, short-time movement. Survey-analytic system applied to this landslide demonstrates validity of the aerial photogrammtry.
\end{abstract}

Keywords : aerial photogrammetry, landslide, monitoring, 3DD-vector, underground sliding geometry

\section{1.はじめに}

斜面災害と呼ばれるものには，山崩れ，崖崩れ，地 すべり，土石流，火山泥流，山津波，鉄砲水，雪崩な どの現象がある。これらは，斜面を構成する物質，斜 面上に存在する物質，または両者を混合した物質が， 重力の作用を受けて集団的に種々の速度で移動するこ とによって引き起こされる現象である。

これらの災害調查にはこれまでに空中写真測量が多 く利用されてきた。それは安全性，迅速性，記録性と いう空中写真測量のみが有する長所によるものであ $3^{1,2), 3)}$ 。

地すべりに対する従来の空中写真測量の利用法をみ ると，災害状況を撮影した空中写真の提供と対策立案

$*$ 信州大学工学部

$* *$ 株式会社 協同測量社

***長野県土木部上田建設事務所

「写真測量とリモートセンシング」Vol. 33, No. 3, 1994
用の地形図の作成が主体であった ${ }^{4), 5)}$ 。本研究は, これ にさらに一歩踏み込んで, 空中写真測量を地すべり機 構の解析に利用するシステムを構築することを目的と する6)

上記の各種斜面災害の中で, 地すべりは他の現象に 比べてつぎのような $2 つ の$ 特徵を持っている：

1) 原形を保ちながら移動する部分が多いため, 時 間差のある複数の写真上で同一の地物を確認でき る。

2 ）移動速度が比較的緩慢であるため, 地表の諸点 の変位を時間差のある空中写真によって追跡でき る。

この点に着目して筆者らは，撮影した日時が異なり 地表形態が変化している 2 枚の空中写真を用いて, 部 分ごとの実体現を繰り返して順次同一の地物を識別 し，当該地物の拡大実体視によって両方の写真上で明 瞭に確認できる点（変位追跡点）をブリックし，ステ コメータで座標を計測して, 両写真から求めた座標差 から変位追跡点の三次元変位ベクトルを検出する手法 を検討してきた77,8)。 
これまでにも洪水流の動態調査 ${ }^{9)}$ や規模なマス ムーブメント（岩なだれ10)・土石流 ${ }^{11}$ ・地すべり5)）の 変位調査に空中写真測量が利用されているが, 現象の とらえ方はかなり巨視的であり, 数 $10 \mathrm{~m}$ 以上の移働量 を扱っている場合が多い。本研究の場合は変位追跡点 の分布密度はこれらの研究の 10 倍以上であり, 数 $10 \mathrm{~cm}$ 以上の移動量を扱うものである。

地すべり地に選定した変位追跡点の三次元変位べク トルを解析して，筆者らはこれまでに地下すべり面の 形状と位置を推定する手法を検討してきた ${ }^{12 \sim 16) 。 た た ゙ ~}$ しこれまでの研究では, 地すべり地全体を一括して解 析して, 地下すべり面形状を単調な連続曲線または連 続曲面として近似するものであった。これは解析に用 いる変位追跡点の数が少なかったためである。変位追 跡は地上測量を主体としていたため, 地形や地物の影 響および作業能率等の関係上, 測点の数が限定された。 しかし上記のような時間差空中写真測量を利用する と, きわめて多くの変位追跡点のデー夕が安全かつ迅 速に得られることが分かった。さらにそのデー夕を解 析していくと地すべり地内でいくつかの移動ブロック を判別でき，ブロックの運動特性から個々のブロック の地下すべり面形状を推定できることが分かった。そ してそれらの曲面を連結してかなり複雑なすべり面形 状の推定が可能となった。

本文はこれらの研究成果を, 長野市広瀬地区に発生 した突発性短期活動型の地すべりに適用したものであ る。

\section{2. 地すべり防災情報提供システムと空中 写真測量}

地すべり災害の防止・回避・軽減等の防災対策を講 ずるためには，まず種々の情報を収集し，これの解析 と検討を通じて適切な計画を立てることが必要であ る。この場合, 空中写真測量を防災情報提供システム の中で, どのように位置付けて利用できるかを検討し てみる。

地すべりに対する防災態勢は積極的防災と消極的防 災に大別できる。前者は地すべりの発生を未然に防ぐ ために抑制的・抑止的な対策を施すもの, 後者は地す べりが発生したのちに拡大防止・再発防止・復旧工事 等の対策を施すものである。

困 1 は, 積極的防災システムを空中写真測量の立場

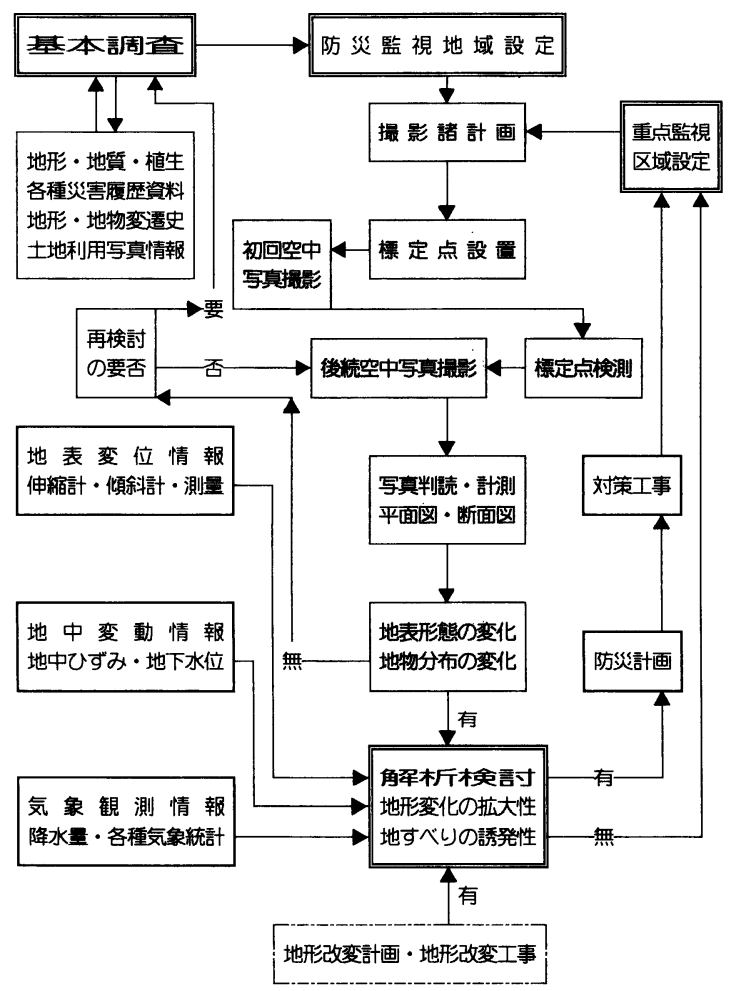

図 1 積極的地すべ防災システムにおける空中写真測 量の利用法

から提案したものである。時間差のある空中写真の判 読と計測によって, 自然的・人工的要因による地形・ 地物の変化が検出される。この情報に図示のような地 表変位情報, 地中変動情報, 気象観測情報等を加之て 総合的に解析し，地すべり発生の危険度を検討した上 で後続の空中写真の撮影時点を定めていく。このシス テムは地すべり防災の理想像であり，これを実現させ るためには, 対象地域の重要度が極めて高く, 行政体 制と予算的な裏付けが整っていることが必要である。 つまり当該地域の防災意識と政治・経済的な背景が支 配的なものとなる。ただし，種々の開発事業に伴う人 工的な地形改変工事を施すような場合は，図 1 の方式 を基本とした監視システムを長期間にわたって義務付 けていくことが必要と考える。

しかしながら現行の防災行政の大部分は「災害が発 生した後に予算が付けられる」というタイプの消極的 防災である。一般に防災対策は，防災事業に着手する 時期によって次のように分類できる。

事前対策型：兆候発生の段階で各種抑制対策を講ずる もの。 
事後対策型：地すべり発生後に拡大防止と抑制を図る もの。

復旧監視型：復旧工事完了後に積極的防災を実施する もの。

空中写真測量を最も有効に利用できるのは事後対策 型の防災システムである。これは次の 2 つの理由によ る。

1）地すべりによる地物の移動は, 通常数 $\mathrm{m}$ 以上に 達するため, 移動前後の空中写真を比較・計測して 地物の移動量を検出できる。

2 ）変動が激しくて現地立入調查が不可能な場合で

も，地すべりの発生と同時に全域的監視測量が可能 である。

図 2 に地すべりに対する消極的防災システムを，空 中写真測量の活用法を中心に示した。事前対策型の検 討に利用できるものは，当該地域を含む各種縮尺の新 旧の空中写真である。地すべりの兆候発生段階での地 表変動量は数 $\mathrm{cm}$ 以下であり, 空中写真測量では検出 できない。

事後対策型の防災システムでは空中写真測量を最大 限に利用できる。地すべり運動のタイプは，短期間に 急激に移動しただけで休止するものから，長年月にわ
たり周期的な移動を繰り返すものまで多種多様ではあ るが, 全体的な移動量はいずれのタイプでも数 $\mathrm{m}$ から 十数 $\mathrm{m}$ に達するので, 地形変化と地物の移動を三次元 的に追跡することは容易である。この場合, 初回の空 中写真撮影を即刻緊急的に実施するほど, 解析に用い る三次元変位ベクトルの精度が高くなる7),8)。そして信 頼度の高い情報を迅速に提供することは, 避難・警戒 態勢をはじめ, 各種の地すべり対策を早期に実現させ る上でも意義がある6)。

復旧監視型の防災システムは, 各種の復旧・防災工 事の完了または進捗状況に合わせて，図 1 に類似した 監視体制を適用するものである。図 2 ではこれを省略 する。

\section{3. 三次元変位べクトルによる地すべり機 構解析システム}

地すべりが発生した場合の, 空中写真測量の実施計 画および複数の時点の撮影で得られた空中写真から変 位追跡点の三次元変位ベクトルを検出する手順に関し ては，すでに本誌30-5(1991) 7)で報告しているので省 略する。

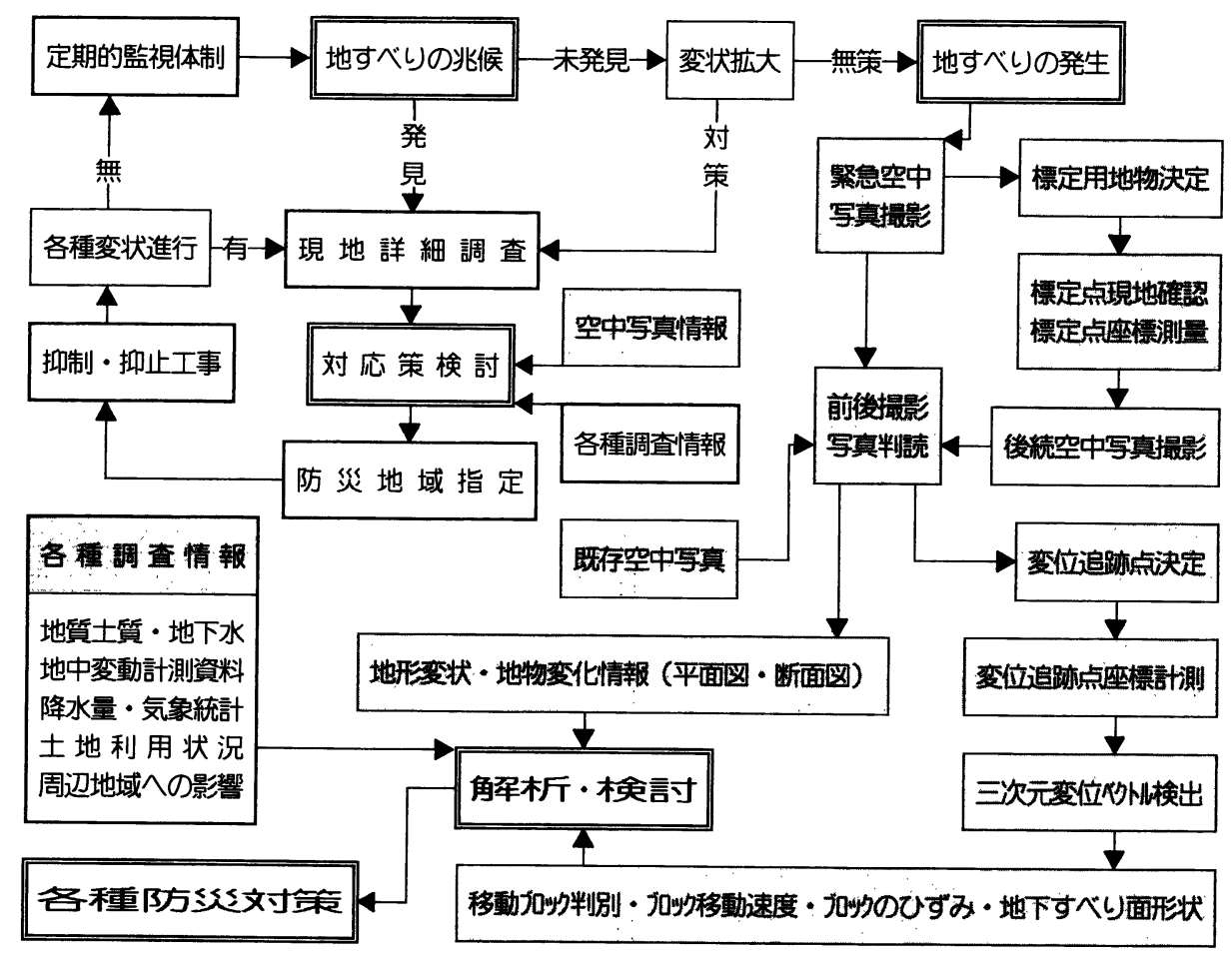

図 2 消極的地すべク防災システムにおける空中写真測量の利用法 


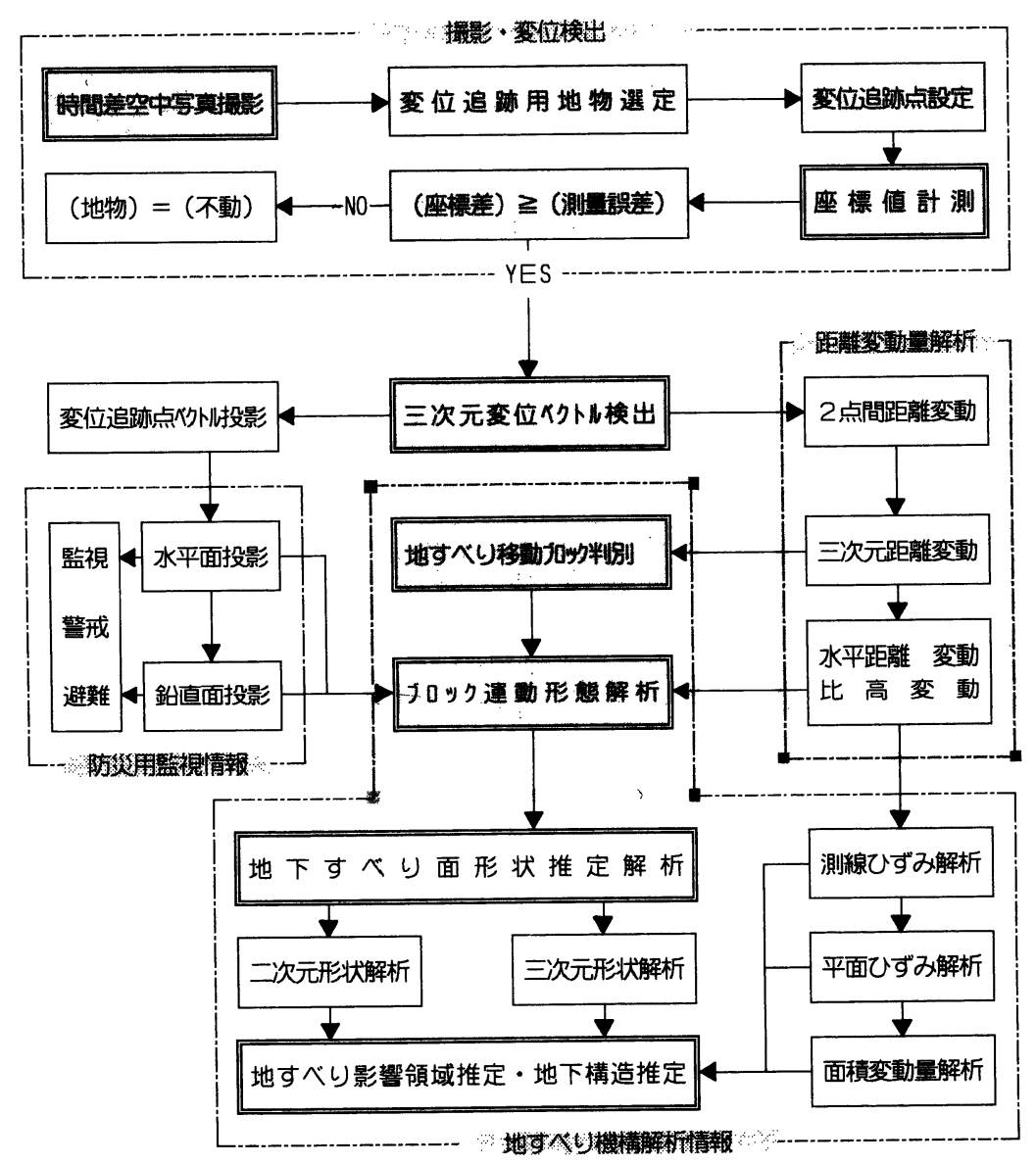

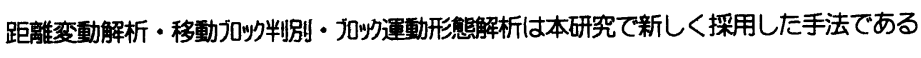

図 3 三次元変位ベクトルによる地すべり機構解析システム

図 3 に, 時間差のある空中写真から三次元変位べク トルを検出し，地すべり防災に利用できる各種の情報 を提供するための解析システムを示す。地すべり地を 撮影した写真上に選定した変位追跡点に対して, 撮影 時点が異なる複数の写真上で計測した座標值に，写真 湘量の誤差以上の座標差が生じている場合, 変位追跡 点は移動しているものと判定して, 座標差から三次元 変位ベクトルを求める。

地すべり挙動を解析する最も直接的な手法は, 三次 元変位べクトルを地形図上に投影して地表各所の移動 状況を把握することである。移動方向と移動速度（移 動量）を観察して，必要に応じて警戒区域や避難区域 を指定する。

また三次元変位ベクトルを, 地形図上の移動方向に ほぼ平行な鉛直投影面上に投影すると，地すべり地域
全体の運動が, 単一の回転または平行移動的なものか, さらに複雑な複合すべり的なものかを判断することが できる。

地すべりの発生によって地中には多くのせん断破壊 面が生ずる。この破壊面で分断された土塊はすべり面 の上を重力の作用によって移動する。移動中の運動形 態に類似性の見られる土塊の集団を移動ブロックとい う。移動ブロックは，地すべり地内で移動している 2 点間の三次元距離が時間的に変化しないこと（距離変 動量が測量誤差以内）および 2 点が比較的近距離にあ ることを条件として，時間差のある空中写真上で計測 した諸点の座標值を解析すれば検出できる。検出され たひとつの移動ブロック上の各点の間で, 水平距離(二 次元距離) と比高 (一次元距離) の変動を解析すると, ブロックの運動形態の特徵がわかる。これよりそのブ 
ロックの直下に位置するすべり面の幾何学的形状特性 を推定することができる17)。

移動ブロック上の 2 点間の距離の変化率（測線ひず み）を用いて，ブロックの平面Uずみや面積変動量が 求められる。これらの情報から, 地すべり地全域にお ける個々の移動ブロックに作用する応力の状態や，圧 縮性の領域と引張性の領域を識別する資料が得られ

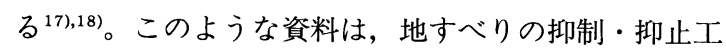
事および復旧工事に関する諸計画の中で有効に利用す ることができる6)。

図 3 に示した地すべり機構解析システムにおいて, 現時点までに筆者らが最も検討を重ね, 実用の可能性 を確認してきたものが, 地下すべり面形状推定解析手 法である。これは, 鉛直投影面上に変位追跡点の三次 元変位べクトルを投影して, 地下すべり面の形状を 種々の曲線または多角形によって推定するものと, 三 次元変位べクトルを直接解析して, 地下すべり面形状 を三次元の連続曲面として推定するものに大別でき る。この解析は三次元変位ベクトルが与えられれば数 時間の解析で解が得られる。よってこれを地下すべり 面の第 1 近似解とみなして, ボーリング等の精密な調 査を行なうための諸計画に利用することができる。ま た場合によってはボーリング調査を省略して, 各種の 防災対策工事の設計と施工に早急に着手することもで きる。

地形困を用いて, 上記の二次元または三次元の推定 すべり面と地表面とが交差する地点を求めていけば, 地すべりの影響が及ぶ領域を地形図上に示すことがで きる。特に, 川の中とか森林や荒地の中に地すべりの 境界部が位置するというような地形的・地物的な原因 で地すべりの境界部を容易に特定できない場合に，こ の手法は非常に有効な手段である。

\section{4. 移動ブロックの判別と移動特性の検討}

\section{1 変位の有無の判別1)}

撮影時点 $T_{1}, T_{2}$ の空中写真上で計測された地表の 変位追跡点 $[\mathrm{i}]$ の (座標値) \pm (誤差) を次の形で表わ す：

$\left\{\begin{array}{l}\text { 時点 } T_{1}: X_{11} \pm m_{\mathrm{X} 11}, Y_{11} \pm m_{\mathrm{Y} 11}, H_{\mathrm{i} 1} \pm m_{\mathrm{H} 11} \\ \text { 時点 } T_{2}: X_{\mathrm{i} 2} \pm m_{\mathrm{X} 12}, Y_{\mathrm{i} 2} \pm m_{\mathrm{Y} 12}, H_{\mathrm{i} 2} \pm m_{\mathrm{H} 12}\end{array}\right\}$ 2 つの時点で計測された座標值の差から三次元変位べ クトルが得られる。ただしこのベクトルには座標計測
の誤差が伝播している。得られたベクトルがこの䛊差 を十分上回っている場合, この点は変位を生じている ものと判定する。判定手法に関しては本誌 30-5 (1991) 7)に詳述してあるので省略する。

\subsection{2 点間の距離変動による移動ブロックの判 別 ${ }^{13), 14)}$}

変位を生じていると判定された複数の変位追跡点に ついて，相互の結合の程度を 2 点 $[\mathrm{i}],[\mathrm{j}]$ 間の三次元 距離の時間的な変化量または線ひずみによって判別す る。

時点 $T(T=1,2)$ における 2 つ変位追跡点 $[\mathrm{i}]$, [j] 間の三次元距離 $S_{\mathrm{ijT}}$ は次式で与えられる：

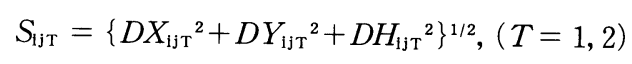

ここに $\mathrm{DX}_{\mathrm{ijT}}, \mathrm{DY}_{\mathrm{ijT}}, \mathrm{DH}_{\mathrm{ijT}}$ は時点 Tにおける [i]， $[\mathrm{j}]$ 点の 3 軸 $(X, Y, H)$ 方向の座標差である。上記の 座標計測の誤差により式(1)の三次元距離に生ずる誤差 $M_{\mathrm{SijT}}$ は :

$$
\begin{aligned}
& M_{\mathrm{SijT}}=\left[\left\{D X_{\mathrm{ijT}}{ }^{2}\left(m_{\mathrm{XIT}}{ }^{2}+{m_{\mathrm{XjT}}}^{2}\right)+D Y_{\mathrm{ijT}}{ }^{2}\left(m_{\mathrm{YiT}}{ }^{2}+m_{\mathrm{YjT}}{ }^{2}\right)\right.\right. \\
& \left.\left.+D{H_{\mathrm{ijT}}}^{2}\left({m_{\mathrm{HiT}}}^{2}+{m_{\mathrm{HjT}}}^{2}\right)\right\} /{S_{\mathrm{ijT}}}^{2}\right]^{1 / 2},(T=1,2)
\end{aligned}
$$

時点 $T_{1}$ から $T_{2}$ に至る間の 2 点間の距離変化量 $D S_{1 \mathrm{j}}$ は :

$$
D S_{\mathrm{lj}}=S_{\mathrm{ij} 2}-S_{\mathrm{ij} 1}
$$

距離変化量 $D S_{\mathrm{ij}}$ に伝播する誤差 $M_{\mathrm{Vij}}$ は：

$$
M_{\mathrm{Vij}}=\left\{M_{\mathrm{Sij} 1}^{2}+M_{\mathrm{Sij} 2}^{2}\right\}^{1 / 2}
$$

地すべり地内には，段差や亀裂で分断されたいくつ かの移動ブロックが生ずる。ここで「個々のブロック はすべり面上をほほ岡体運動的に移動し, ブロックを 構成する地山の変形は移動量に比べて無視できるほど 微小である」と仮定すれば, 次の手順で移動ブロック を判別できる：

1）地すべり地内で地表に変位を生じている点を検 出する。

2 ）地表に散発している段差や亀裂等の相互の距離 の最大值の $1 / 2 \sim 1 / 3$ の距離を目安として，それ以内 の距離にとどまる変位追跡点 $[\mathrm{i}],[\mathrm{j}]$ を選ぶ。

3) 2 点 [i], [j] 間の三次元距離の時間的変化量 $\mathrm{DS}_{\mathrm{ij}}$ が次の条件を満足する場合, 2 点は同一のブ ロック上に存在するものと判定する。 


$$
\left|D S_{\mathrm{lj}}\right|<K \cdot M_{\mathrm{Vij}}
$$

ここに $K(>1)$ は, 現地の地表変状と各ブロックの移 動量を考慮して試行的に与える係数である。

また三次元距離の変化量のかわりに三次元線ひずみ を用いた場合, 式(5)のかわりに次式を用いて判定する。

$$
\left|D S_{\mathrm{ij}} / S_{\mathrm{ij} 1}\right|<K \cdot\left\{S_{\mathrm{ij} 2}{ }^{2} \cdot M_{\mathrm{S} \mid j 1}{ }^{2}+S_{\mathrm{ij} 1}{ }^{2} \cdot M_{\mathrm{Sij} 2}{ }^{2}\right\}^{1 / 2} / S_{\mathrm{ij} 1}{ }^{2}
$$

\section{3 移動ブロックの運動特性の検討}

Uとつのブロックを構成する地山の変形が, ブロッ クの移動量に比べて非常に小さい場合，そのブロック は地下に発生したすべり面の上を剛体的に移動してい ると見なすことができる。この場合，ブロック上に設 けた多くの変位追跡点に関して, 任意の 2 点間の水平 距離と比高は, 地下すべり面の幾何形状に応じて次の ような変動を示す：

1 ) 平行移動型：層すべりのようにブロックが地中の

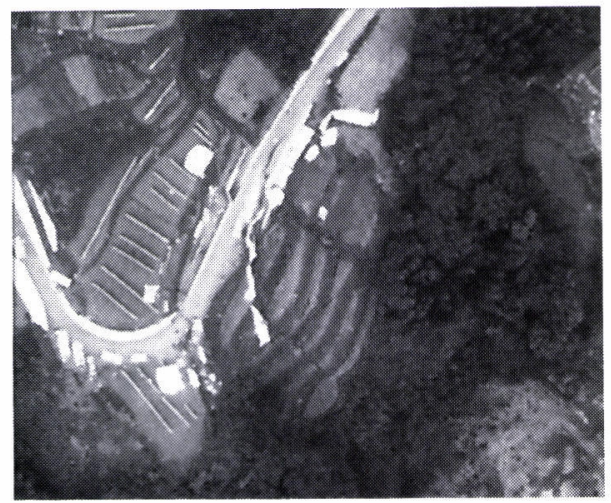

写真 1 長野市広瀬地区地すべクの空中写真

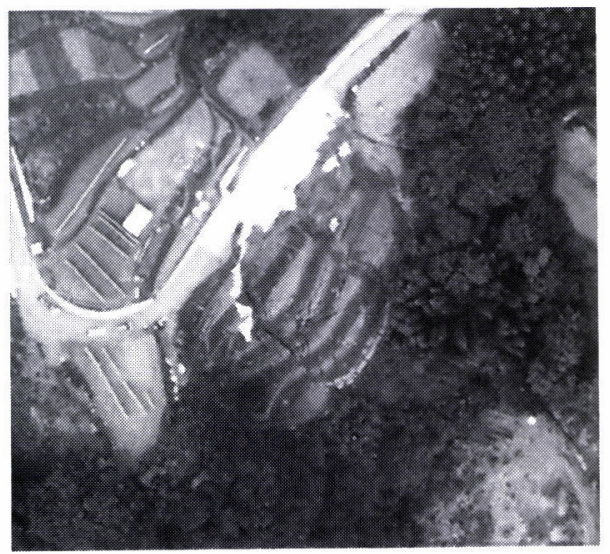

写真 2 長野市広瀬地区地すべりの空中写真：地すべり発生 7 日後（10月10日14時22分撮影）

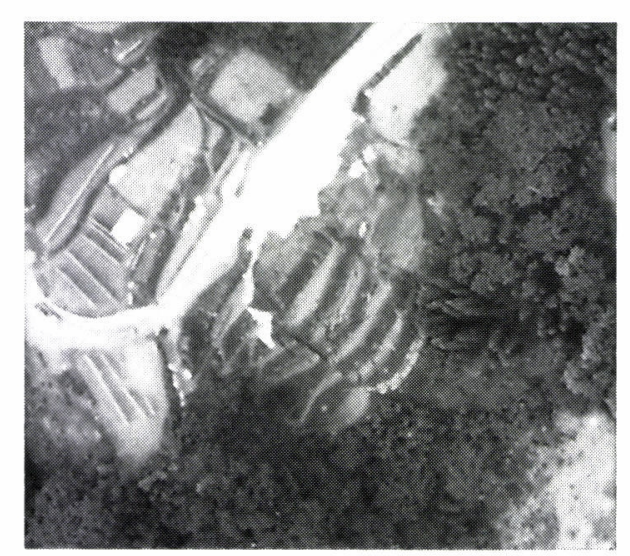

地層境界面に沿って移動する場合は，地表諸点の移動 軌跡は地層面と平行になる。よってブロック上の 2 点 間の水平距離と比高は, ブロックが直線状に移動する とき一定值を保つ。

2 ) 凹面回転型：回転性地すべりの地下すべり面の形 状は, 一般に円弧または複心円に類似した上方に凹面 をなす曲面となる。すべり面上を一方向に移動するブ ロック上の 2 点間の距離は, ブロックの移動に伴い, 三次元距離は一定值を保ち, 二次元距離（水平距離） は増加，一次元距離（比高）は減少していく。ただし 地すべクの脚部付近のブロックでは, 水平距離が減少, 比高が増加するという，これとは逆の現象を示すこと がある。

3）凸面回転型：表層すべりまたは地質構造的な要因 により，地下すべり面が上方に凸の曲面形状をなす場 合，地山の移動にともなうブロック上の 2 点間の距離 は, 三次元距離は一定, 二次元距離は減少, 一次元距 離は增加という特性を示す。

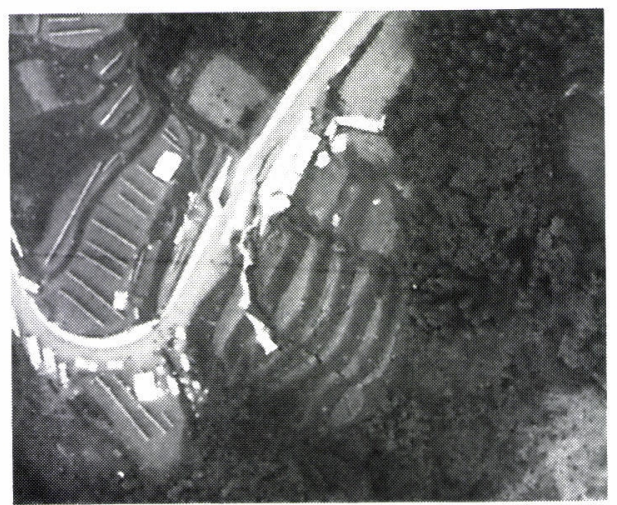

地すべり発生 2 日後（10月 5 日15時24分撮影） 


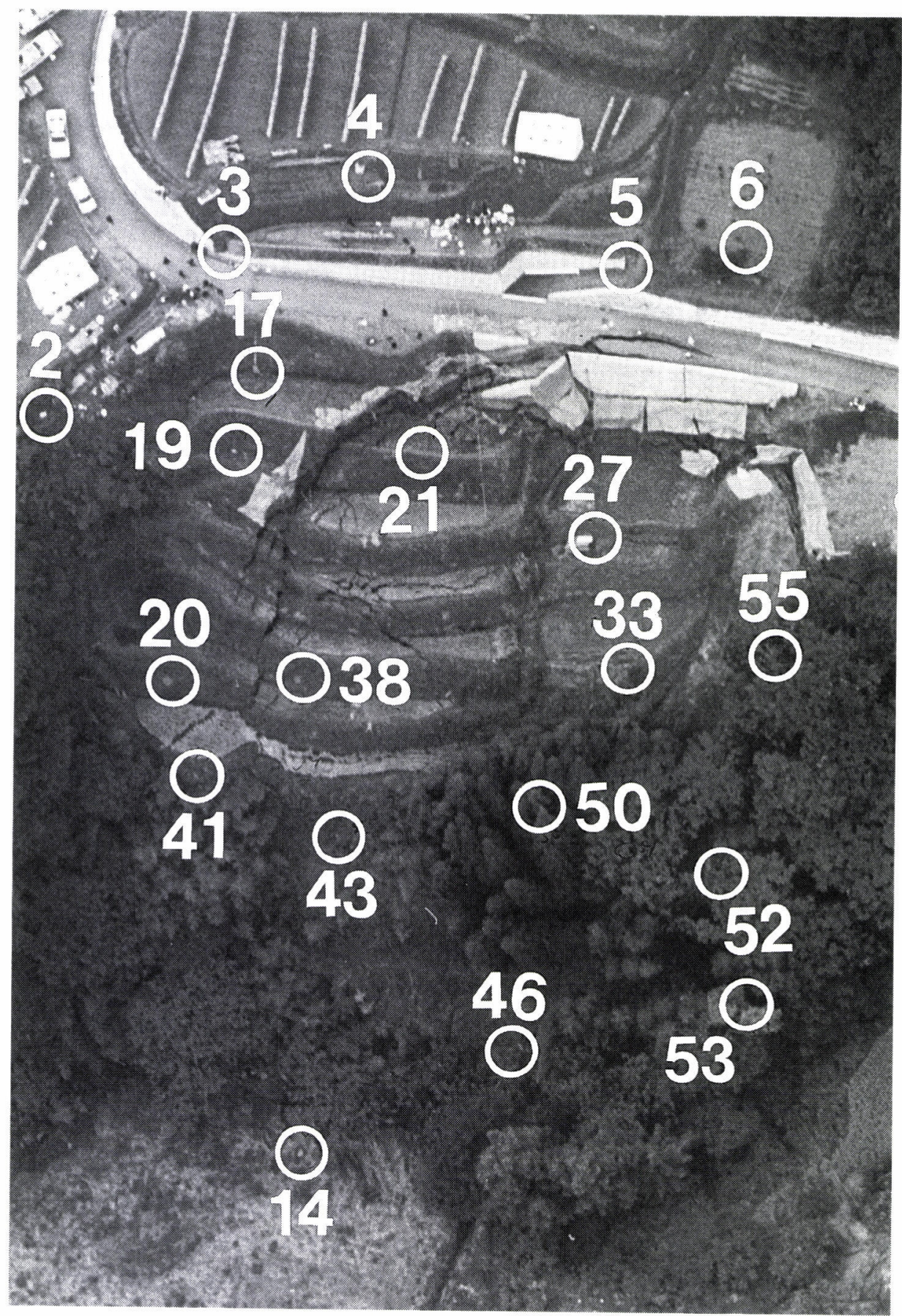

写真 3 長野市広瀬地区地すべクの空中写真上における変位追跡点の設定 30番台までの追跡点は地表の物体 40番台の追跡点は雑草地と藪の中 50 番台の追跡点は森林中の樹冠部

\section{4 地すべり地への適用例と考察}

上記の解析手法を，長野市広瀬地区に発生した地す べりに適用し，若干の考察を示す。この地すべりは谷
川に面した斜面の，水田・荒地・山林を含む幅 $55 \mathrm{~m}$ ，長 さ65m ほどの範囲に発生した突発性短期活動型の地 すべりで，顕著な活動は 4 日間（1989年10月 3 日〜 6 
日）であったが，谷川の堰止めによる土石流の発生が 懸念され，下流の住居地域に対する防災上，重大な関 心事となった。空中写真の撮影は 10 月 5 日と 10 月 10 日 に試行した。

筆者らは，この地すべりに対して空中写真測量の適 用性を検討することを目的として，10月 5 日15時 24 分 と10月10日14時22分の 2 時点で空中写真を撮影した。 両写真とも, カメラは RC-10 2536, レンズは UAG. I .6037 (c=153.43mm) を用い, 対象地域に対する撮 影対地高度は平均 $840 \mathrm{~m}$, 縮尺 $1 / 5600$ である。

写真 1 は 10 月 5 日の撮影である。地すべり地の頭部 にあたる道路上に発生した段差と，道路から下方に続 く水田に発生した亀裂が顕著である。地すべりの脚部 は谷川に面した山林に覆われ，写真上では確認できな い。

写真 2 は10月10日の撮影である。水田に発生した亀 裂がさらに伸び，各所で段差に成長している。

これらの写真は緊急撮影のため, 標定点を設置して いない。よって, 過去に別の目的で空中写真測量を実 施したことのある既存の空中写真（1984年 5 月24日撮 影，カメラは RC-10 2536，レンズは NAG. II.7100 $(c=213.80 \mathrm{~mm})$, 縮尺 $1 / 8000)$ を解析図化機 $(\mathrm{DSR} \cdot 11)$ で空中三角測量成果により標定したのち, 写真 1 と 2 の上でも明瞭に同一物と判定できる地物をパスポイン トとして 8 点選び, それらの座標を測定した。なお現 代ならぱ, 写真 1 と 2 の上で共通な地物の座標を GPS で現地測定する方法が実用的であろう。

本研究では, 対地標定で生ずる写真 1 と写真 2 の相 対的な誤差を極力小さくする必要がある。よって新た に両写真上で地すべり地から十分離れた安定した場所 から共通のパスポイントを 8 点選定した7)。

地すべり地内の地物の上に選んだ変位追跡点の例を 写真 3 に示す。擁壁や道路などの人工物, 農地の境界 点, 識別しやすい岩の角などが適当であるが, 前後の 撮影写真の経過日数が少ないため, 畑の中の野菜の株 や放置された物体なども有効に利用できた。ただし地 すべり地の中部から下部は雑草地や山林のため, 雑草 の間に見える地表面や樹木の頂点などを変位追跡点に 用いた。

写真 1 と写真 2 に共通の変位追跡点をプリックする 作業は，実体移写機（PUG・4）を用いてタイポイント 選点プリックの手法を応用した。まず PUG・4に写真 1 の左側と写真 2 の右側のポジフィルムをセットして実
体視する。このとき地すべりによる地表変状の大きい 場所では実体像がくずれるが，破壊や変形の生じてい ない部分では, 同一の地物は重なり合って局部的な実 体視ができる。よって写真像の拡大率を20倍前後で統 一し，目標物を部分ごとに実体視しながら，視差を完 全に消去して両方のフィルム上に同一の変位追跡点を 定めてプリックした7)。

図 4 は, 解析図化機 (DSR・11) を用いて写真 1 と写 真 2 の変位追跡点の三次元座標を求め, 各点の座標差 から水平変位ベクトルを求めたものである。

\section{a）変位の有無の判別17)}

図 4 に示した変位追跡点の中で，40番台の測点は灌 木混じりの荒地と雑草地に，50番台の測点は山林中の 樹木の樹冠部に設けたものである。これらの測点の配 置は不均等で密度も低く, 座標計測の精度も低いが, 変位の有無の判別には十分寄与している。測点 41 と 47 は平面図上では上方の斜面に発生した段差に包み込ま れるような位置にあるが，水平変位は微小である。し かし鉛直方向では $20 \mathrm{~cm}$ と $30 \mathrm{~cm}$ 程度の変動を生じて いる。測点 54 と 55 これと類似の位置にあり，水平変 位は微小であるが鉛直方向の変動は $70 \mathrm{~cm}$ と $60 \mathrm{~cm}$ で ある。樹上測点52の変位ベクトルは地すべりによる樹 木の傾動の影響をかなり受けている。測点50にも傾動 の影響が若干見られる。測点51では樹木の傾動はなく， ベクトルは上部の斜面上の測点 $32,33,34$ 等の変位へ クトルと傾向がよく一致しており信頼度は高い。

この地すべり地では初回の撮影後における顕著な地 表変動の期間は 1 日弱であったが, この手法で地すべ りによる変動領域をかなり明確に判別できることが分 かる。初回の撮影を敏速に実施していれば変動領域の 判別と地表諸点の変位ベクトルの信頼度はさらに高ま るはずである。

b ）移動ブロックの判別 ${ }^{17)}$ 前記の 2 回の空中写真測 量で得られた変位追跡点の座標計測值を用いて, 式(3) によって地すべり地内の任意の $2 つ の$ 変位追跡点間の 三次元距離の時間的変動量 $(D S)$ を計算する。そして 式(5)または式(6)を用いて移動ブロックを判別する。

図 5 は, 前記 $4.2 の 1) ， 2 ， 3) の$ 判別手順により, 結 合度の高い 2 点間を直線で結んだものである。実線は 時間の経過とともに 2 点間の三次元距離が減少したも の, 破線は距離が増加したものである。以下に要点を 示す。

1) この地すべりの規模 $(55 \mathrm{~m} \times 65 \mathrm{~m})$ から見て， 2 


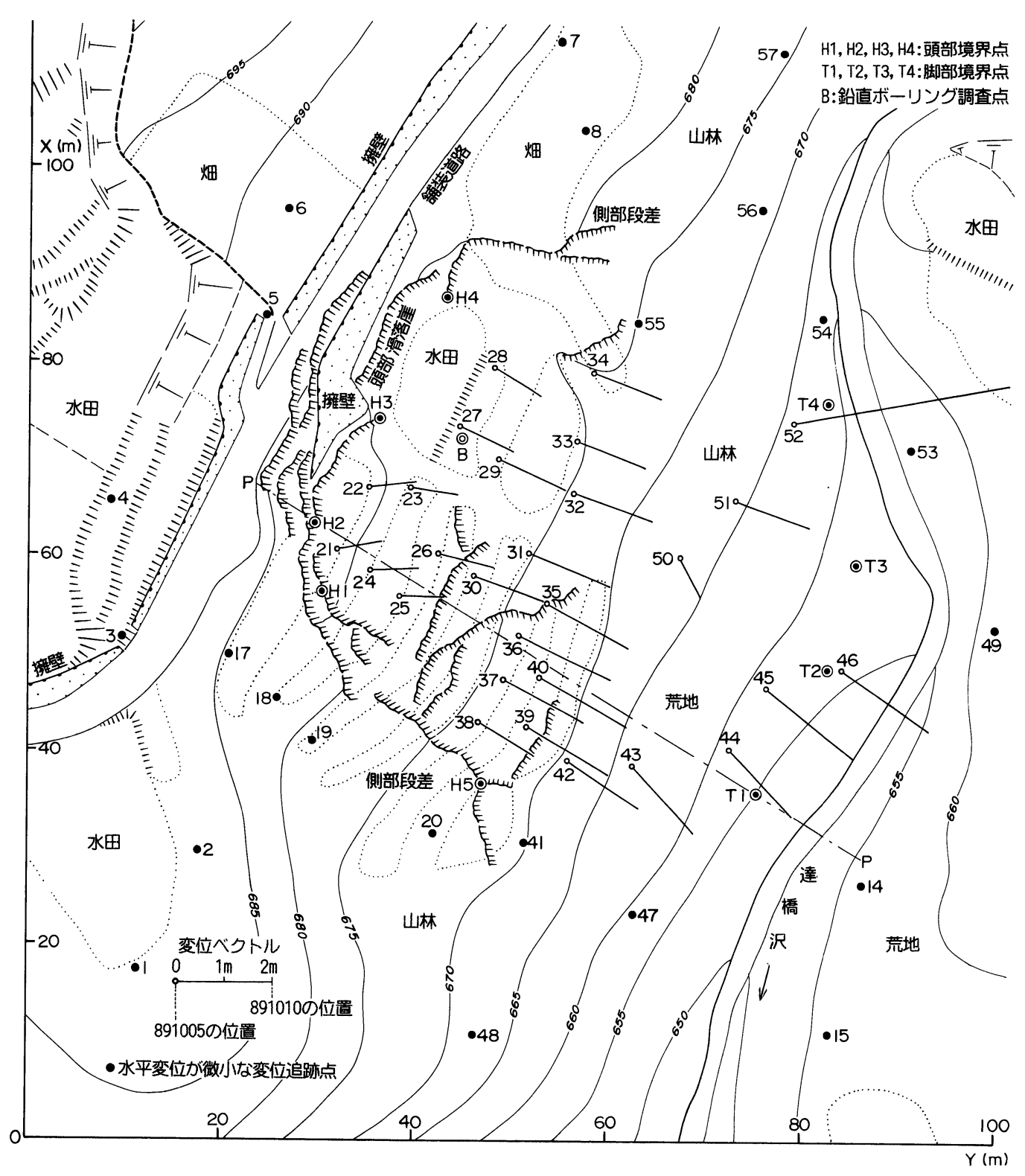

图 4 長野市広瀬地区の地表変状と地表諸点の水平変位ベクトル

点間の三次元距離が $30 \mathrm{~m}$ 以内の位置にあるすべて の変位追跡点の組み合わせについて検討した。

2) 式(5)または(6)による判別基準として, 三次元距 離変動量については $|D S|<10,15,20 \mathrm{~cm}$, 線ひず みについては $|D S / S|<1.0,1.5,2.0 \%$ 各条件 を与えて結合線図を作成したところ， $|D S|<10$ $\mathrm{cm}$ または $|D S / S|<1 \%$ 条件を満たす場合が, 地表に発生した段差や亀裂等の形態と最もよく対応 する結果となった。よって図 5 にはこの判別基準に
基づいた結合線図を示した。

判別の結果，地すべりによる顕著な移動を生じてい る領域には移動ブロック(1)と(2)が，その周辺には微動 ブロック(3)と(4)と(5)が現れている。各ブロック中の結 合線の距離変動量と線ひずみの絶対值に関する最大 值, 最小值, 平均值を表 1 に示す。

この表の参考值は, 10 月 5 日と 10 月 10 日の写真上に おける個々の変位追跡点について, 標定・プリック・ 座標計測の条件を種々組み合わせて得られた合計 12 組 


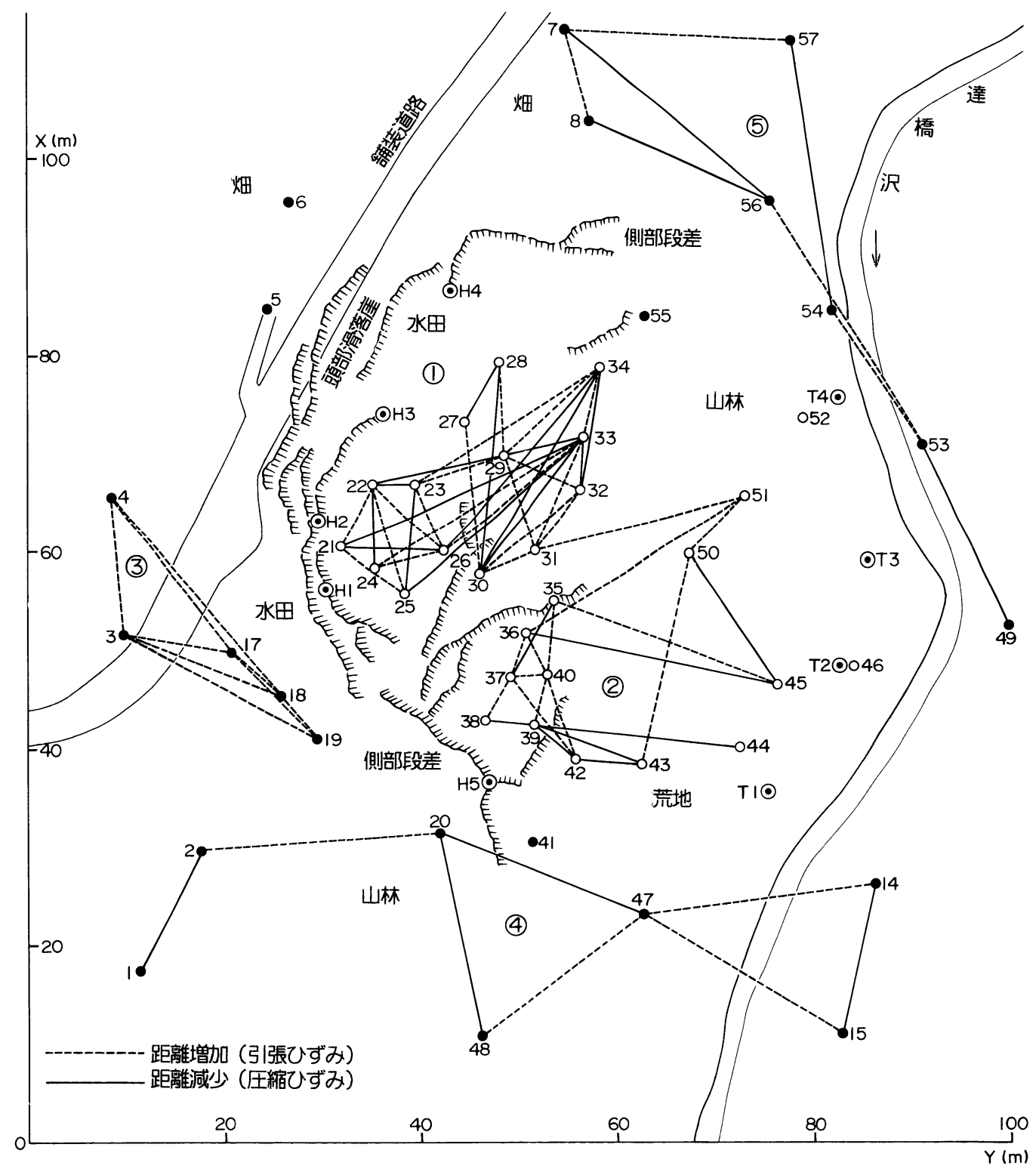

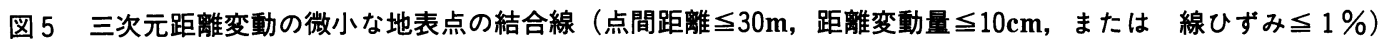

の座標値から求めた平均二乗誤差 (本誌30-5(1991) 参 照) 7)を当該写真の当該点に対する測量によって生ず る座標誤差とみなして, ブロック上で選定した任意の 2 点間の距離変動量に伝播する誤差を式(4)で， 2 点間 の距離のUずみに伝播する誤差を式(6)の右辺 $(K=1$ とする）で計算して, 当該ブロック上に存在するすべ ての 2 点の組み合わせで得られた值を平均したもので ある。したがって表 1 の参考值は, ブロック上の 2 点 間の距離（ひずみ）変動量に及ぼす測量誤差の平均值

\section{とみなすことができる。}

表 1 では最大值は参考值を上回るが，平均値の中に も参考值を上回るものが見られる。これは地すべりブ ロックの変形によるものと考える。最小值では変動量 が 0 に近いものもある。要するに個々の地すべりブ ロックの上には， 2 点間の距離がほとんど変動しない ものから，この表の最大值の程度まで変動するものが 混在している。地すべりで地山に破壊が生ずる場合の Uずみは，地質と含水状態によってかなりの幅がある 
表 1 各ブロックにおける三次元距離変動量と線ひずみ（絶対值）

\begin{tabular}{|c|c|c|c|c|c|c|c|c|c|}
\hline \multirow{2}{*}{$\begin{array}{l}j 0 y \text { 的 } \\
\text { 番号 }\end{array}$} & \multicolumn{3}{|c|}{ 三次元距離変動量 } & \multirow{2}{*}{$\frac{(\mathrm{m})}{\text { 参考値 }}$} & \multicolumn{3}{|c|}{ 三次元ひずみ変動量 } & $(\%)$ & \multirow{2}{*}{ 言己事 } \\
\hline & 最大值 & 最小值 & 平均值 & & 最大值 & 最小値 & 平均値 & 参考值 & \\
\hline 10 & 146 & 0 & 0.049 & 046 & 0.0 & 000 & 55 & .004 & 移重 \\
\hline (2) & 0.250 & 0.003 & 0.080 & 0.0 & 0. & 0. & 0.009 & 0.007 & 移重 \\
\hline 3 & 0.094 & 0.008 & 0.038 & 0.038 & 0.0 & 0.001 & 0.002 & 0.003 & 微動領域 \\
\hline (4) & 0.092 & 0.015 & 0.048 & 0.087 & 0.004 & 0.001 & 0.002 & 0.003 & 微動領域 \\
\hline$\Rightarrow$ & 0.089 & 0.005 & 0.051 & 0.059 & 0.009 & 0.000 & 0.003 & 0.003 & 不動領域 \\
\hline
\end{tabular}

参考値 : 空中写真測量の誤差が距離変動量またはひずみ変動量に伝播する値の平均値

が，本文で対象とした地すべりでは数\%の線ひずみま では亀裂や段差が生じていない。

この地すべり地の内部の移動ブロックは, (1)と (2)の 2 つに大別される。図 5 を見ると，これら 2 つの移動 ブロックの間には段差が多発している。段差をはさむ 2 つの変位追跡点間の三次元線ひずみ $(D S / S)$ は 31 と 35 の間で+6\%，30と36の間で+5\%，25と37の間 で+6\%に達している。

図 5 において，地すべり地の周辺の変位追跡点の結 合線は, 地すべり地内の変位追跡点の結合線と完全に 分離している。変位追跡点の中で比較的近距離にあり ながら他と結合されない単独の点がある。点52は樹木 の傾動成分が大きいために，また点 41 と点55は水平変 位は小さいが比高変動が大きいために近くの点と結合 されない。地すべり地の頭部付近では, 近距離に位置 する点 5 と点 6 が相互に結合されない。また地すべり 地の側部付近でも近距離にありながら［ブロック(3)の 点 3 と点19）は［ブロック(4)の点 2 と点20］に対して 不連続である。これらの一帯には，破壊には至らない けれども地山のUずみによる微動が各所に生じてい る。よってこの一带を微動ブロックとみなす。ブロッ ク(5)おいては変位追跡点の結合線が途中で断絶しな い。また点 54 と点 56 は対岸の点 53 と連結する。いずれ も測量精度の低い50番台の樹上測点であるにもかかわ らずこのような結果が得られているのは, 地盤の変形 が少なく樹木にも傾動が生じていないことを意味す る。よってブロック(5の一帯は不動ブロックとみなす。

c ）地下すべり面の幾何形状特性の推定 ${ }^{17)}$

前記 (4.3) で述べたように, 移動ブロック上の 2 点 間の水平距離と比高の変動を観察して, ブロック直下 の地下すべり面の幾何形状の特性を推定する。解析の
結果を図 6 に示す。移動ブロック(1)と(2)について, 4.3 で述べた移動ブロックの運動特性を，2つの変位追跡 点間の水平距離と比高の変動を解析することにより, さらに詳細に@からゆまでのブロックが推定される。 ブロック(9は平行移動型である。この特性を示す変位 追跡点 $(35 ， 36 ， 37 ， 38 ， 40)$ を点線で結んだ。ブロッ クモは凸面回転型で，この特性を示す変位追跡点 $(37$, 39，40，42，43）を太い実線で結ぶ。(a)(b)(d)(の各 ブロックはいずれも凹面回転型と推定されるもので, 変位追跡点の間を細い実線で結んだ。破線で示したブ ロックゆについては次節で述べる。なお次節の解析と の関連上，この図には，b）で用いた移動ブロックの判 別条件よりも大きい距離変動を生じた 2 点間を結合し た線分も図示してある。

\section{5. 地下すべク面形状の推定}

\section{1 解析手法の改良}

地すべり地における地表の変位ベクトルを用いて地 下すべり面の形状を推定する解析理論は「移動土塊の 変形はすべり面上を移動する土塊の移動量に比べて無 視できる」という仮定に立脚している。これまでに検 討してきた解析手法は, 二次元解析法と三次元解析法 に大別できる。

二次元解析法は, 地表諸点の三次元変位ベクトルを, 地すべりの平均的な移動方向と平行な鉛直投影面上に 投影して解析するもので，円弧すべり面法 ${ }^{12)}$ 多角形 法 $^{13,199}$ 高次曲線法 ${ }^{14)}$ 複合円弧法 ${ }^{16)}$ な゙がある。三次元 解析法は, 三次元変位ベクトルを直接解析して地下す べり面を高次の連続曲面方程式で近似するものであ

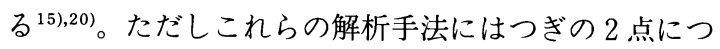




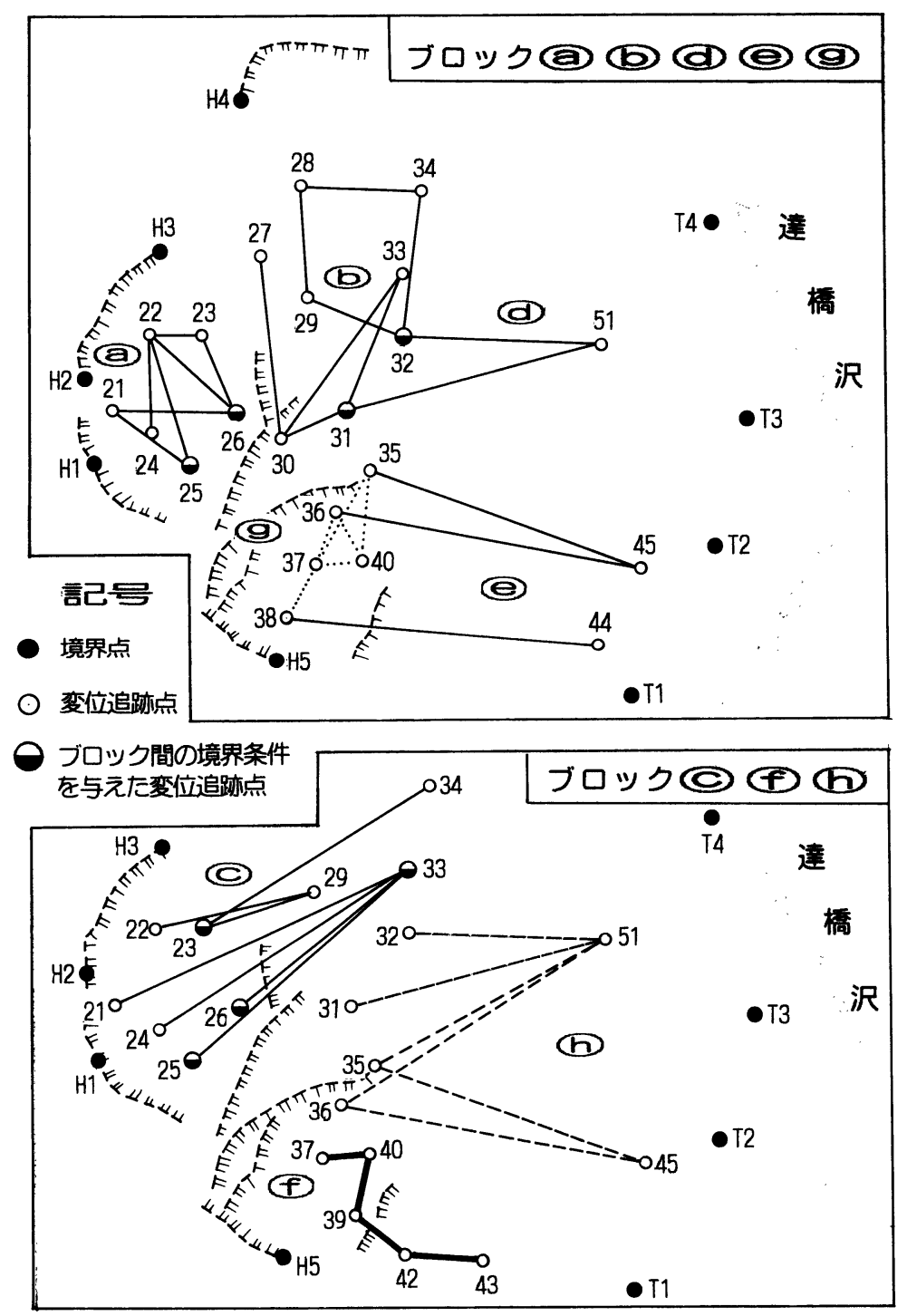

図 6 運動特性の共通するブロックと地下すべク面推定解析用の境界点

いて問題が残つていた。

1 ）多角形法と複合円弧法を除く他の手法は，すべ ク面形状を単一の連続曲線（面）のみで推定してし まう。

2 ）複合円弧法を除く他の手法は，地すべり地内の 移動土塊はすべて一体化して移動するものと仮定し ている。

地質構造的な影響を受けるすべり面の形状には，単 純な連続曲線（面）のみで表わせないものがある。ま た前節の解析例で明らかなように，地すべり地内には 複数の移動ブロックが発生する場合が多い。
本稿はこれらの問題点を解決するために，これまで の解析手法につぎのような改良を加えた。

[ステップ 1] 変位追跡点の座標值の時間的変動を解 析して移動ブロックを区分する。

[ステップ 2] 個々の移動ブロックごとに三次元解析 法を適用してすべり曲面の方程式を求 める。

[ステップ 3］複数の移動ブロックで得られた曲面の 重量平均法によってすべり曲面の等高 線を求める。

この手法によって上記 2 点の問題は解決できる。 


\section{2 三次元すべク曲面推定理論 ${ }^{15) 20)}$}

地下のすべり面を連続した曲面で表し得るものと考 える。本稿ではこれをつぎの二次曲面方程式で表わ す：

$$
H=a X^{2}+b X Y+c Y^{2}+d X+e Y+f
$$

ここに $H$ は標高, $X, Y$ は平面座標値である。

移動ブロックを包囲するような形態で地表に生じた 亀裂や段差は，地下に発生したすべり面と地表面との 交わりである。亀裂や段差の発生場所で解析用の三次 元座標を与える点を境界点と呼ぶ。式(7)の曲面はこの 境界点を通る。この場合, Uとつの境界点 $(\mathrm{B})$ の座標 を $(X, Y, H)_{\mathrm{B}}$ とすれば次式が成り立たなければなら ない：

$$
H_{\mathrm{B}}=a X_{\mathrm{B}}^{2}+b X_{\mathrm{B}} Y_{\mathrm{B}}+c{Y_{\mathrm{B}}}^{2}+d X_{\mathrm{B}}+e Y_{\mathrm{B}}+f
$$

前記のように移動ブロックは地下に形成されたすべ り面の上を固体のような状態を保って移動すると仮定 すれば，ブロックの地表面に設けた変位追跡点から地 下のすべり面までの深さは，変位追跡点の移動量に関 係なく一定值を保つことになる。いま, 変位追跡点 (i) の直下のすべり面の深さを $D_{1}$, 観測時点 $(T)$ におけ るこの点の座標を $(X, Y, H)_{\mathrm{iT}}$ とすれば，式(7)から次 の関係が得られる。ただしすべり面の深さ $D_{1}$ は未知量 である。

$$
H_{\mathrm{TT}}-D_{1}=a X_{\mathrm{iT}}^{2}+b X_{\mathrm{iT}} Y_{\mathrm{iT}}+c Y_{\mathrm{iT}}^{2}+d X_{\mathrm{iT}}+e Y_{\mathrm{IT}}+f
$$

変位追跡点と境界点の座標值はいずれも測定值であ
るために䛊差をともなう。これに加えて上記の仮定に 起因する誤差も介入するため，式(8)，(9)にはつぎのよ うな残差が生ずる：

$$
V_{\mathrm{B}}=a X_{\mathrm{B}}^{2}+b X_{\mathrm{B}} Y_{\mathrm{B}}+c Y_{\mathrm{B}}^{2}+d X_{\mathrm{B}}+e Y_{\mathrm{B}}+f-H_{\mathrm{B}}(10)
$$$$
V_{\mathrm{iT}}=a X_{\mathrm{iT}}^{2}+b X_{\mathrm{iT}} Y_{\mathrm{iT}}+c Y_{\mathrm{IT}}^{2}+d X_{\mathrm{IT}}+e Y_{\mathrm{IT}}+f+D_{\mathrm{1}}-H_{\mathrm{iT}}
$$

ここで最小二乗法の原理を用いて，曲面方程式のパ ラメー夕 $(a, b, c, d, e, f)$ および各変位追跡点の直下 のすべり面の深さ $\left(D_{1}\right)$ を定める。いま境界点の総数 を $\mathrm{P}$ 個, 変位追跡点の総数を $\mathrm{Q}$ 個とすれば, 目的関数 $\Omega$ はつぎのように表わされる：

$$
\Omega=\left[w_{\mathrm{B}} \cdot V_{\mathrm{B}}^{2}\right]_{\mathrm{B}=1}^{\mathrm{P}}+\left[w_{\mathrm{iT}}\left[V_{\mathrm{iT}}^{2}\right]_{\mathrm{T}=1}^{\mathrm{U}}\right]_{\mathrm{i}=1}^{\mathrm{Q}}
$$

ここに $w_{\mathrm{B}}, w_{\mathrm{TT}}$ は重み, $\mathrm{U}$ は変位追跡点 $(\mathrm{i})$ の観測時 点の総数である。 $w_{\mathrm{B}}, w_{\mathrm{IT}}$ の与え方は文献10)による。

式(12)を 6 個のパラメータ: $a, b, c, d, e, f$ および $\mathrm{Q}$ 個の変位追跡点におけるすべり面の深さ： $D_{1}, \cdots$, $D_{1}, \cdots, D_{\mathrm{Q}}$ でそれぞれ偏微分したものを 0 に等置する と, $6+\mathrm{Q}$ 本の方程式が得られる。これを連立に解い て未知量を定める。

\section{3 地すべり地への適用例と考察}

この解析手法を図 6 に示す各ブロックに適用した解 析結果を表 2 に示す。この表には解析に使用した変位

\begin{tabular}{|c|c|c|c|c|c|c|c|c|}
\hline \multirow{2}{*}{$\begin{array}{l}\text { joyn } \\
\text { 番号 }\end{array}$} & \multicolumn{2}{|c|}{ 解析に使用したテータ点 } & \multicolumn{6}{|c|}{ すべり面形状方程式のバラメータ } \\
\hline & 変 位追跡点 & \begin{tabular}{|lll} 
境 & 界 \\
\end{tabular} & $\bar{a}$ & $\mathrm{~b}$ & C & $\mathrm{d}$ & e & $f$ \\
\hline (a) & $21 \cdot 22 \cdot 23 \cdot 24 \cdot 25 \cdot 26$ & $\mathrm{H} 1 \cdot \mathrm{H} 2 \cdot \mathrm{H} 3$ & 0.082 & -0.048 & 0.044 & -8.63 & -2.01 & 1010 \\
\hline (b) & $27 \cdot 28 \cdot 29 \cdot 30 \cdot 31 \cdot 32 \cdot 33 \cdot 34$ & $\mathrm{H} 3 \cdot \mathrm{H} 4$ & 0.072 & 0.008 & 0.030 & -11.43 & -4.75 & 1247 \\
\hline (C) & $21 \cdot 22 \cdot 23 \cdot 24 \cdot 25 \cdot 26 \cdot 29 \cdot 33 \cdot 34$ & $23 \cdot 33$ & 0.039 & -0.037 & 0.027 & -4.78 & -1.31 & 925 \\
\hline (d) & $31 \cdot 32 \cdot 51$ & $\mathrm{~T} 3 \cdot \mathrm{T} 4 \cdot 31 \cdot 32$ & 0.089 & 0.032 & 0.028 & -14.98 & -6.06 & 1397 \\
\hline$\Theta$ & $35 \cdot 36 \cdot 38 \cdot 44 \cdot 45$ & $\mathrm{~T} 1 \cdot \mathrm{T} 2 \cdot \mathrm{H} 5$ & 0.038 & 0.052 & 0.029 & -6.28 & -5.94 & 973 \\
\hline $\boldsymbol{F}$ & $37 \cdot 39 \cdot 40 \cdot 42 \cdot 43$ & $25 \cdot 26$ & -0.087 & -0.064 & -0.013 & 11.35 & 3.93 & 312 \\
\hline (9) & $35 \cdot 36 \cdot 37 \cdot 38 \cdot 40$ & $25 \cdot 26$ & & & & 0.81 & 0.02 & 617 \\
\hline (h) & $31 \cdot 32 \cdot 35 \cdot 36 \cdot 45 \cdot 51$ & T2.T3 & -0.176 & -0.170 & -0.018 & 31.95 & 12.66 & 709 \\
\hline
\end{tabular}
追跡点と境界点および地下すべり面方程式の 6 個のパ ラメータが示してある。境界点としては次の 3 種類を 用いた。

表 2 運動特性の共通したブロック別に解析した地下すべり面形状方程式のパラメータ 
$\mathrm{H} 1, \mathrm{H} 2, \mathrm{H} 3, \mathrm{H} 4, \mathrm{H} 5$ ：頭部と側部の滑落段差の明瞭な 地点

T1, T2, T3, T4:

脚部隆起と押出崩落の発生した 地点

23, 25, 26, 31, 32, 33 ：ブロック (a)とブロックbの解析 で得られたすべり面の，当該変 位追跡点の直下の位置

図6のブロックゆは，図 5 のブロック(1)とブロック (2)の境界部にあたる。この領域は山林と荒地で, 変位 追跡点の密度も精度もともに低い。図 4 に示して水平 変位べクトルの形態も吟味して, 信頼度の高い変位追 跡点にしぼった結合線図がブロック円である。解析の 結果を表 2 で見ると，このブロックの地下すべり面の 形状は上方に凸型の曲面となっている。

図 7 は境界点 $\mathrm{H} 2$ と T1を結ぶ断面 $\mathrm{PP}$ (図 4 ・図 8 参 照）上に投影した地形断面図とブロック@@丹の解析 で得られた地下すべり曲面の断面図である。各ブロッ クで推定された曲面を用いてつぎの手順で地下すべり 面の位置を推定した。

1) 各ブロックの中心部付近のすべり面形状は, 当 該ブロックの解析で得られた曲面形状を用いる。

2 ）隣接ブロックとの境界部付近のすべり面形状 は，2つ以上のブロックの解析で得られた曲面につ いて，同一地点におけるすべり面の標高（深度）を 比較して $3 \mathrm{~m}$ 以内の較差のものを重み付き平均寸 る。

地下すべり面の標高を求める地点における各ブロッ
クの曲面の標高に与える重みは, ブロックの解析に用 いた変位追跡点の数と座標計測の精度，およびブロッ クの中心部からその地点までの距離を考慮して定め る。

この手順によって図示のようなすべり面形状が得ら れた。但し，図中の水平距離 $60 \mathrm{~m} \sim 75 \mathrm{~m}$ の区間は，ブ ロック@とブロックゆの解析で得られた曲面を重み付 き平均したものである。

また，河川に面した脚部では表層の滑落による二次 的なすべりのために現地と整合しない部分が生じてい る。よってすべり面は現地変状に整合するように描い た。このような二次的なすべりは図 7 の頭部の道路直 下の 2 本の亀裂部にも発生しているものと考えられ る。

図8 は, 四 6 に示した各ブロックの境界部における 地下すべり面の標高を, 現地長 $5 \mathrm{~m} \times 5 \mathrm{~m}$ の方眼の交 点の位置で比較し, 較差が $3 \mathrm{~m}$ 以内の曲面を平均して 推定したものである。方眼の交点の標高を用いて図示 のような地下すべり面の等高線図が得られる。

これより地下すべり面と地表面とが交差する線を求 めた。この線は地すべり地の頭部から側部にわたって 発生した段差の形態と良く整合している。図において 境界点 H1, H2, H3, H4, H5は, この地すべりの発生当 初に現われた地表変状である。さらに外周の段差は数 日後に現われた二次的なすべりによるものである。

推定すべり面と地表面との交線は, 脚部の境界点 T2, T3の位置との整合性が良くない。この原因のひと

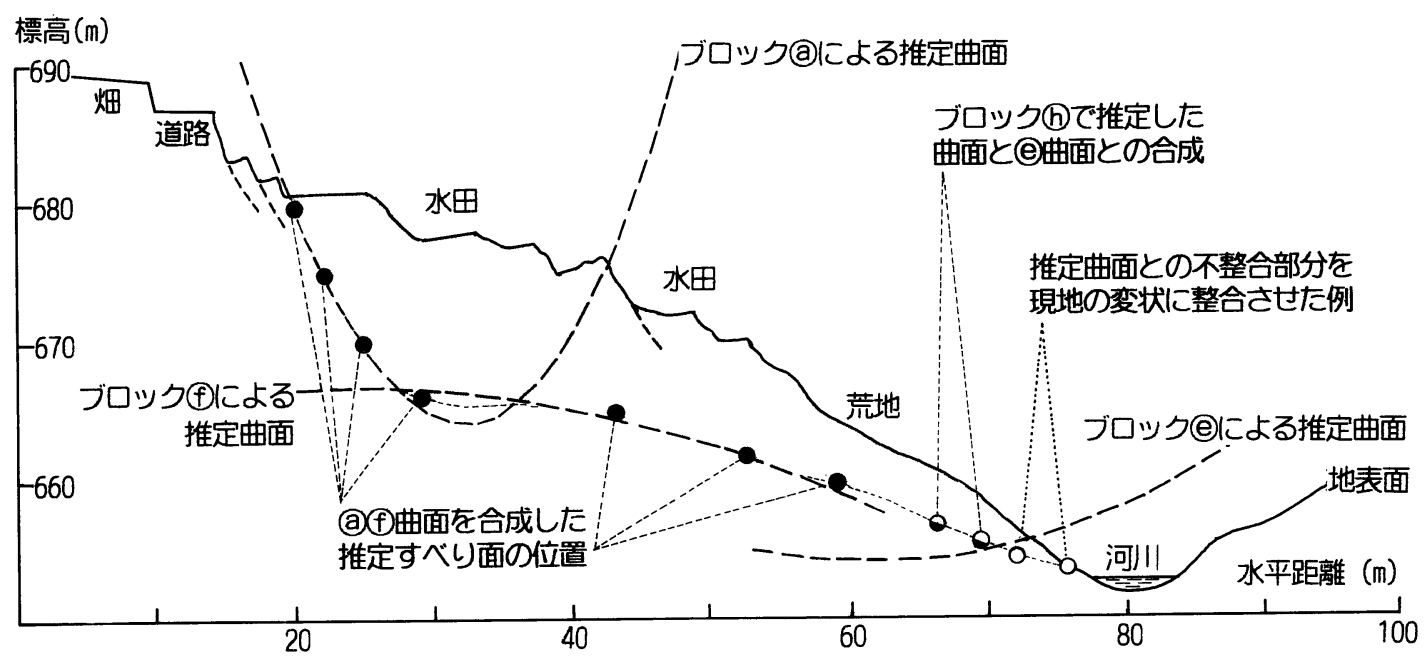

图 7 断面 PP 上における各ブロックの推定曲面と地すべクによる移動土塊の推定 


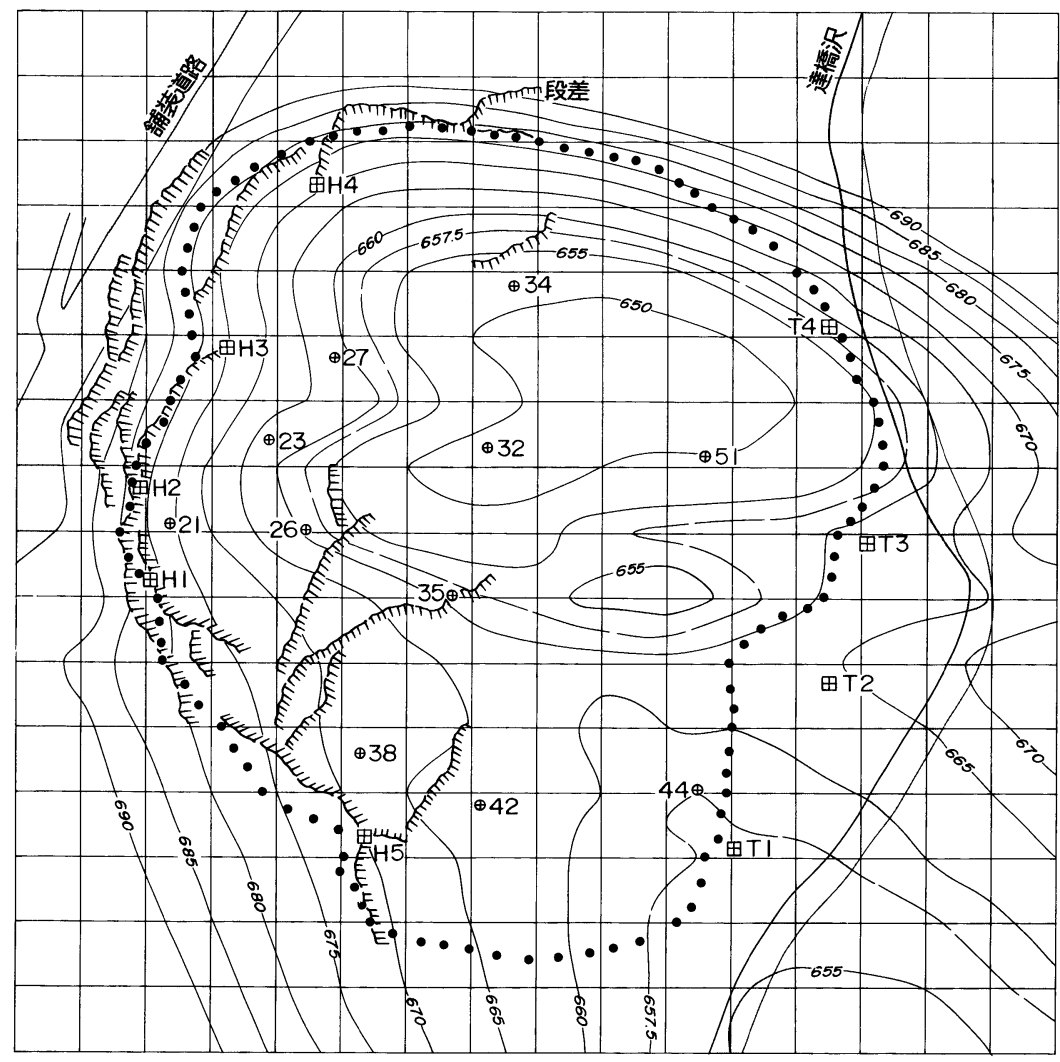

$\oplus$ 変位追跡点

田 頭部・脚部境界点

・ 地表面と推定すべり面の交線

目 8 推定地下すべク面の等高線図・すべ面と地表面との交線・地表に発生した段差の 形状 (方眼： $5 \mathrm{~m} \times 5 \mathrm{~m})$

(地下すべク面の深さ $)=($ 変位追跡点の標高 $)-($ すべク面等高線図から求めた当該地点 の標高) 21(5m), 23(9m), 26(14m), 27(8m), 32(11m), 34(18m), 35(14m), 38(6m), $42(6 \mathrm{~m}), 44(3 \mathrm{~m}), 51(20 \mathrm{~m}:$ 樹上点)

つに，この付近では図 4 に見るように解析デー夕を提 供する変位追跡点の密度が非常に低いことがあげられ る。なお地質構造的に見ると，河川が屈曲するこの付 近には巨礫を主体とする強固な河岸段丘が発達してお $\eta ，$ 強度的には上方の斜面と異なったものとなってい る。

\section{6.おわりに}

本研究を通じて, 時間差のある空中写真測量は地す べり挙動の監視のみならず，移動ブロックの判別と地 下すべり面形状の推定に有効に利用できることが分 かった。特に地上測量に比べて非常に多くの変位追跡 点の座標値を安全かつ迅速に得られる点が有利であ
る。

時間差空中写真測量で得られる多数の変位追跡デー 夕によりここれまで地上測量を中心に検討してきた， 連続的で単純な地下すべり面形状の推定手法から『移 動ブロックごとに求めた三次元曲面を合成して複雑な すべり面形状を推定する』という，より信頼度の高い 解析手法を完成させることができた。地すべりに対す る時間差空中写真測量を成功させる鉄則は，初回の撮 影を一刻も早く敏速に実施することである。

おわりに，長野市広瀬地区の地すべりに対して，各 種の資料の提供をいただいた長野県土木部，長野市役 所，日本物理探鉱株式会社に謝意を表します。

(受付1994.1.10, 受理1994.5.20) 


\section{引用文献・参考文献}

1 ) 日本写真測量学会 : 空中写真の判読と利用, 鹿島出版 会, pp. 105-116, 1980 .

2 ）武田裕幸・今村遼平：建設技術者のための空中写真判 読, 共立出版, pp.110-134.

3 ) 今井篤夫：斜面災害における空中写真の利用, 写真測 量とリモートセンシング, 特集号II, 土木分野における 写真測量, pp.18-27, 1983.

4) 打荻珠男：航空写真による地すべり状況の測定, 地す べり, 5-2, pp.23-27, 1968.

5 ）長岡正利：長野市地附山地すべりの災害状況と地形変 化, 測量, 35-10, pp.23-31, 1985.

6 ）吉澤：地すべり防災対策のための測量情報解析システ ムの構築, 応用測量論文集, 4-1, pp.109-120, 1993.

7 ）吉澤・西澤・三澤・根岸：地すべりの挙動解析におけ る写真測量の応用, 写真測量とリモートセンシング, 30-5, pp. 8-20, 1991.

8 ）吉澤・丸山・他：空中写真測量による地すべり情報の 提供とすべり面の解析, 地すべり, 27-4, pp.9-17, 1991.

9 ）木下良作：写真測量による洪水流調査, 写真測量とリ モートセンシング，特集号II，土木分野における写真測 量, pp.28-33, 1983.

10) Zhang Renlin: Application of the Image Interpretation from Airphotos Taken in the Different Periods for the Debris Flow Rsearch, International Archives of Photogrammetry and Remote Sensing, Vol. XXIX, Commission VII, pp. 381-388, 1992.

11）柳川雅一：1978年 5 月に発生した妙高火山白田切川の
土石流と地形の関係, 写真測量とリモートセンシング, Vol.17, No.2, pp.11-20, 1978.

12）吉澤・細川：地すべり地における地表変位測量デー夕 を用いた円弧すべりの解析, 地すべり，23-4, pp.13-23， 1987 .

13）吉澤：多角形法による地下すべり面の解析, 地すべり, 25-2, pp.9-17, 1988.

14）吉澤：地上測量による地下すべり面形状および地すべ り影響圈の推定，地すべり，26-3, pp.28-39, 1989.

15）吉澤 - 宮澤：地下すべり面推定における三次元移動軌 跡法の改良, 地すべり, 28-4, pp.6-14, 1992.

16）吉澤・条野・西澤：各種の回転半径をもつ円弧の結合 による地下すべり面形状の推定, 地すべり，29-3, pp.10-17, 1993.

17）吉澤・酒井・宮野尾：時間差空中写真と地すべり機構 解析, 日本写真測量学会秋季学術講演会発表論文集, pp.171-176, 1993.

18）吉澤：奈良尾地すべり地における地すべり挙動の精密 測量とその解析，地すべり，15-3，pp.11-16, 1978.

19) M. Carter - S.P. Bentley: The Geometry of Slip Surfaces beneath Landslides: Prediction from Surface Movemenmts, CAN. GEOTECH, Journal, Vol. 22, 1985.

20) Norikazu Yoshizawa: Landslide Montoring for Presumption of Underground Slide Surface, International Archives of Photogrammetry and Remote Sensing, Vol. XXIX, Commission VII, pp. 478-485, 1992. 